\title{
TOURISM COMPETITIVENESS OF POLAND COMPARED WITH OTHER EUROPEAN COUNTRIES
}

\author{
Agnieszka Brelik ${ }^{1}$, Dr.hab., prof.; Gunta Grinberga-Zalite ${ }^{2}$, Dr.oec., assoc.prof. \\ ${ }^{1}$ West Pomeranian University of Technology in Szczecin, ${ }^{2}$ Latvia University of Life Sciences and Technologies
}

\begin{abstract}
The article deals with the issues of Poland's tourism competitiveness and the role of rural tourism development. The study reveals that tourism can be an important area of the local economy and act as a stimulus of endogenous development. To assess the competitiveness of tourism regions in the Europe, the authors used the TTCI (Travel \& Tourism Competitiveness Index) covering the period from 2015 to 2017. The aim of the research was focused on the evaluation of Poland's tourism competitiveness compared with other European countries. The analysis of TTCI data reveals that Poland's tourism competitiveness shows a positive trend. In the analysed period, the most competitive countries were Spain, France, Germany and the United Kingdom and the closest competitors of Poland were Hungary, Bulgaria, Slovakia and Latvia. The deeper insights in comparing the attractiveness of Poland compared with other East European and Balkan countries give evidence that the nature and landscape values of agricultural land of Poland are very highly rated in Europe, and the only Poland's indicator which stands out from the overall tourism indicators is country's international openness, which in reality is only indirectly linked with Poland's nature and landscape attractiveness as it mainly depends on the EU geopolitical aspects. The research is based on the analysis of qualitative and quantitative data available in secondary information sources; the methods of induction and deduction, analysis and synthesis are used to reach the aim of the research.
\end{abstract}

Key words: tourism economy, rural tourism, competitiveness.

JEL code: Z30, Z32.

\section{Introduction}

Nowadays the process of diversifying economic activity in rural areas and incorporating new nonagricultural and non-productive functions into the rural space is inevitable. The process is closely associated with the policies of the all-in-one and sustainable development of villages and the dominant feature of the tourist ${ }^{3}$. Based on research and expertise (Rosner, 2002; Stanny, 2013; Rosner, Stanny 2007), Polish countryside is spatially differentiated, both in the sense of the level of social and economic development. The country is divided into Western Poland, which is much better developed, and Eastern Poland with low economic potential and unfavourable demographic structures, with young people having a tendency to migrate - their escape to large economic centres for work and better living conditions. This situation forces us to seek new solutions to this problem and to commence the vocational activation of the rural population, with a particular focus on multifunctionality and creating non-agricultural jobs (Zarebski, 2015). According to Zvirbule and Dobele (2018), the tourism industry represents one of the opportunities for economic growth in the country. As the examples of delimitation of rural areas indicate, tourism can be a crucial sector of the local economy and act as a stimulus of endogenous development. On the basis of the concept of alternative tourism (in the 80 s of the $20^{\text {th }}$ century put forth as an alternative to mass tourism), concepts pointing to the need for the development of tourism with respect to the broader human environment emerged. The concept of eco-development and then sustainable development takes into account the possibility

\footnotetext{
agnieszka.brelik@zut.edu.pl, Tel. +48606529592

2 gunta.grinberga@llu.Iv, Tel. +371 29463545 3 Analysis of the development of tourist function usually applies to a limited area being a properly defined territory. This is usually an area defined by common. The main reason is the small significance of such comparisons for the economy of a single country. However, when such a comparison is an element enabling the classification of countries due to the degree of tourist development, and therefore is a tool to indicate the countries most developed in terms of tourism, then this information becomes valuable due to the possibility of obtaining an appropriate pattern of development. Measurement of the development of the tourist function is carried out by using several indicators, among which should be mentioned best known traditional indicators, i.e.: Baretje'a-Deferta, Schneider, Charvata or Deferta www.ue.katowice.pl/fileadmin/_migrated/content_uploads/8_A.R.Szromek_Pomiar_Funkcji_Turystycznej....pdf].
} 
of natural „ingrowing" of tourism into regional and local social structures and the natural environment (Kraciuk, 2016). This increases the importance of knowledge, innovation, creativity and entrepreneurship. These features become important factors in the development of both businesses, farms, local environments, regions, and the entire country's economy. The key task is shaping entrepreneurial attitudes, the consequence of which are specific activities in various spheres of social and economic life (Krzyzanowska, Sikorska-Wolak, 2010, p. 39). According to Wilkin (Multi-functionality of agriculture..., 2010) multifunctional use of resources of social capital and the implementation of new non-agricultural features into the rural space, such as production, services and commerce, result in economic diversification of rural areas, reducing the role of agriculture, and thus creating new jobs, reducing unemployment, searching for new sources of income in occupations related to the agriculture and using rural manufacturing resources (Roszkowska-Wise 2010, 2014, p. 113-126; Wisniewska, 2008, p. 221-225; Zawadzki, 2014, p. 315-329). Rural tourism has a huge potential owing to natural and heritage culture potential (Grinberga-Zalite et al., 2018), thus the resources of a given area: natural and cultural environment, infrastructure, facilities and equipment for visitors are a determinant of the attractiveness of the region. A tourist attraction is not only determined by its tourist values (natural and cultural), but also travel products offered, land use, the availability of physical and economic, historical heritage, social and cultural events as well as sports facilities (Davidson,1996; Gaworecki, 2000).

How to extract tourist regions ${ }^{1}$ is not clear, as different concepts on this topic appear in the literature of the subject. The indisputable criterion, taken into account by all the authors, is tourist attractions; however, in case of other features which should characterise this type of region, there is No longer such a compliance required. One of the older concepts assumes that the tourist region is an area that performs tourist function on the basis of homogeneity of the features of geographical environment and internal service links. It is a recognition of the economic existence of spatial organisation in the system with the team-oriented devices adapted to the environmental conditions and social relations (Warszynska, Jackowski, 1974, p. 31). In this perspective, a tourist region was identified with the administration, which became the economic specialization of functions, and it was usually characterised by the uneven distribution of values of geographical environment.

\section{Tourism competitiveness of Poland in relation to other European countries}

The competitiveness ${ }^{2}$ of the areas of the tourist reception is based on three groups of objective and subjective variables: factors of the location of the area; the tourist potential; and assessing the image of the area (Zemla, 2010). Despite the fact that competitiveness is the subject of numerous scientific research works, the literature of the subject lacks a clear and generally accepted definition of that concept. There is a consensus, however, that competitiveness is a complex category, and consequently, determining its essence requires decomposition into constituent elements, i.e. dimensions of competitiveness. In literature, the competitiveness of a region is defined as the ability to adapt to new tasks and social, economic and environmental challenges, and the ability to create alternative conditions (possibilities) of the development, which help to maintain or strengthen the position of the region, both at home and abroad (Markowski, 2005, p. 25; Ratajczak, 2008, p. 300).

${ }^{1}$ Tourist region (destination) is defined as the area that attracts the attention of tourists from a considerable distance through its points of interest, providing them with paid accommodation.

2 Economic literature indicates that the competition is the process by which market participants, in order to realize their interests, try to present more favourable offers in terms of price, quality or other characteristics affecting the decision to enter into a transaction (Kamerschen, McKenzie, Nardinelli 1992 , p. 47). The competitiveness of national economies will therefore be the ability of the country to produce and distribute the material goods and intangible goods competitive in relation to those that are produced in other countries, assuming the increasing standard of living of societies (Scott 1985). 
The competitive region is the one that creates a favourable climate for the development of entrepreneurship and innovation in the market economy, enabling businesses to achieve high economic efficiency and acts on the inclusion of existing work in the processes of management, thanks to which it raises the level and the quality of life in the region (Skinny-Hyski, 2009, p. 35). This approach refers to the concept of tourist attractiveness of areas and includes a group of features related to tourism in the broad sense, which is the subject of interest (demand) of potential tourists. The competitive region, according to Klamut M. $(2008$, p. 47) is the one which enables creating new structural combinations by using human and physical resources, favouring the commercialisation of its products. Competitive regions, according to Czudec W. (2010, p. 1), are separate or uniform areas similar in terms of investment offers or specialized public services, agricultural regions with similar specialization, industrial and raw material regions, tourist regions with similar offers, and finally innovative and learning regions. Factors shaping the competitiveness of the region depend mainly on the potential inherent in the region (natural or historical conditions), the activity of the local authorities in the area of planning and implementation of regional and economic policy of the country, structural policy and cohesion policy of the European Union (Richter-Kazmierska, 2007, p. 195-196). Taking into account the site factors in space, internal factors (e.g. the pension position, territorial organization factors, and infrastructure) are considered, i.e. permanent part of the region, and the external factors, which have been retrieved from outside the region (Grabowski, 2008, p. 157). The rivalry between the regions is now becoming more and more sophisticated. The areas which are winning are those that prioritise new management methods and are able to bring out their potential (Czudec, 2010, p. 1). The subject of competition between regions may be the acquisition of tourists, and the competitiveness in this case is based on attractive natural resources and cultural heritage and their respective exposure and use. The role that the region can play in the economy, whether Polish or European, depends on its competitive position. The potential of competitiveness determines the type, the size and persistence of competitive advantage. Competitive advantage is the basis for the formulation of such an offer in the market, which will allow the achievement of a specific position.

In the market of tourist services, small units such as a commune, and even a single tourist attraction, compete with each other. The development of competition in the market of tourist services both local, regional, internal, European, and global forces the subjects to the market to search for new forms of shaping their competitiveness (Dabrowska, 2006, p. 114).

The aim of the current research was focused on the evaluation of Poland's tourism competitiveness compared with other European countries. The research tasks subordinated to the achievement of the current research aim were: 1 ) to analyse the theoretical aspects of tourism economics and the growing importance of rural tourism opportunities for countries' regional development; 2) to analyse tourism competitiveness of European countries in 2015-2017;3) to evaluate Poland's tourism competitiveness compared with other East European and Balkan countries by identifying its current strength and weaknesses.

\section{Methodology}

In order to assess the specificity of the tourism economy and the competitiveness of the tourist regions, the authors used TTCI-Travel \& Tourism Competitiveness Index data proposed by the World Economic Forum. The design of the TTCI indicator is composed of three levels. Accordingly, the first level is made up of four sub-indexes: the environment for tourism, policy in the area of tourism, infrastructure, natural resources and cultural heritage. Moreover, each sub-index includes so-called 
pillars that make up the next level of the structure indicator TTCI, which was the focus of the particular study. The research is based on the analysis of TTCI quantitative data and quantitative data available in secondary information sources. The methods of induction and deduction, analysis and synthesis are used to reach the aim of the research and make justified conclusions.

\section{Research results}

According to the United Nations World Tourism Organisation (UNWTO, s.a.), today Europe is the largest receiving continent for international tourists. In order to have a closer insight into the attractiveness of various European countries, the World Economic Forum annually issues tourism performance overview summarized in Travel and Tourism Competitiveness Index that includes factors determining the level of competitiveness regions. Thanks to it, it is possible to identify and compare the competitiveness of countries, assess the impact of individual factors on the competitiveness and identify the strengths and weaknesses of the tourist regions. A total of 14 pillars can be extracted in the TTCI version in 2015 and 2017. In turn, each pillar consists of several subindexes. Accordingly, in total 90 indicators were used in TTCI index. The value of the TTCI index in 2015 for Poland was 4.08 (on a scale of 1-7), which is $27^{\text {th }}$ place in the ranking of European countries, where in 2017 it increased by 0.03 and reached the $25^{\text {th }}$ position.

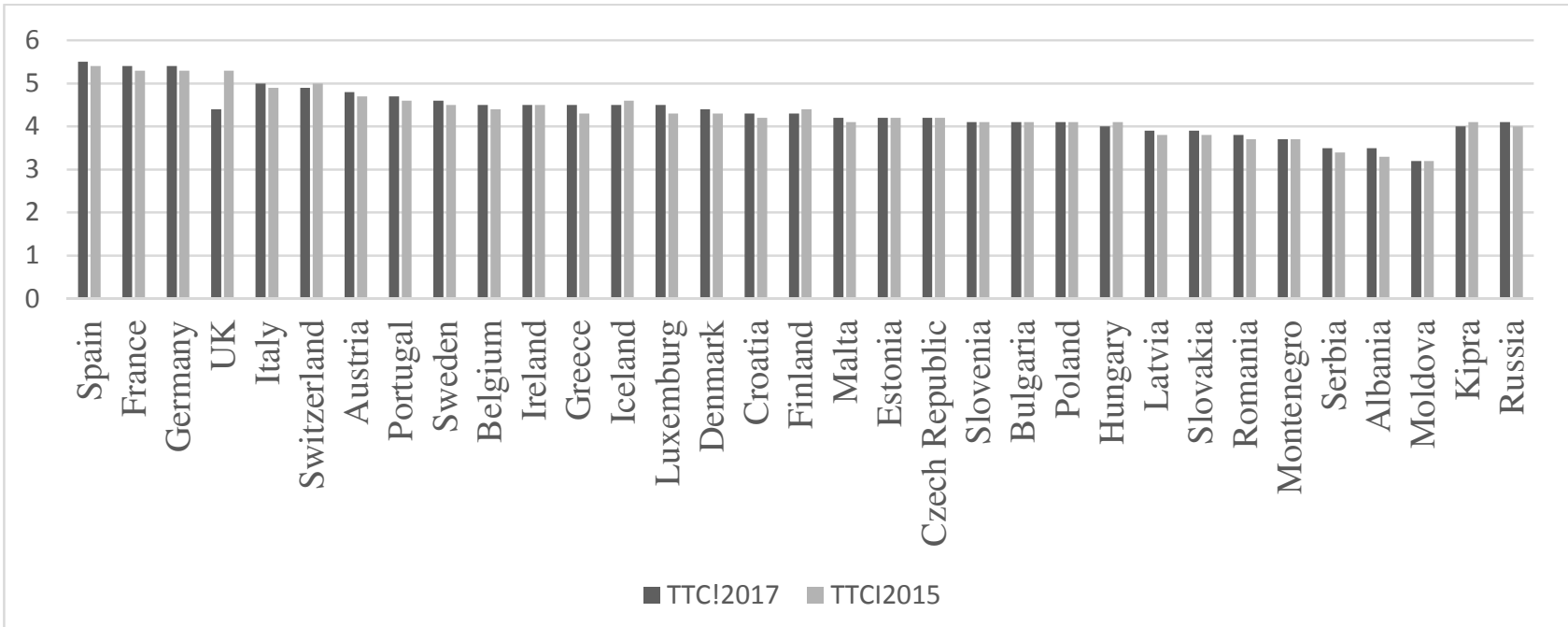

Source: Author's calculation based on The Travel and Tourism..., 2015, 2017

Fig. 1. European countries' tourism competitiveness index values in 2015 and 2017 (scale 1-7)

The data presented in The Travel \& Tourism Competitiveness Report show that during the analysed period the leaders in the tourism competitiveness are Spain, France, Germany and the United Kingdom and their index values show a positive trend in the analysed 2-year period. The closest competitors of Poland that have obtained approximately same values are the Czech Republic, Hungary, Bulgaria, Slovakia and Latvia.

To have a closer insight into the attractiveness of Poland and its direct competitors, an in-depth analysis of the competitiveness of Poland as a tourist region in comparison to East European and Balkan countries was conducted by analysing the individual indicators of the second pillar in 2017 (Figure 2). The data of Figure 2 reveal that in half of the fourteen analysed indicators, the position of Poland is better than the average results of the Balkans and Eastern Europe. 


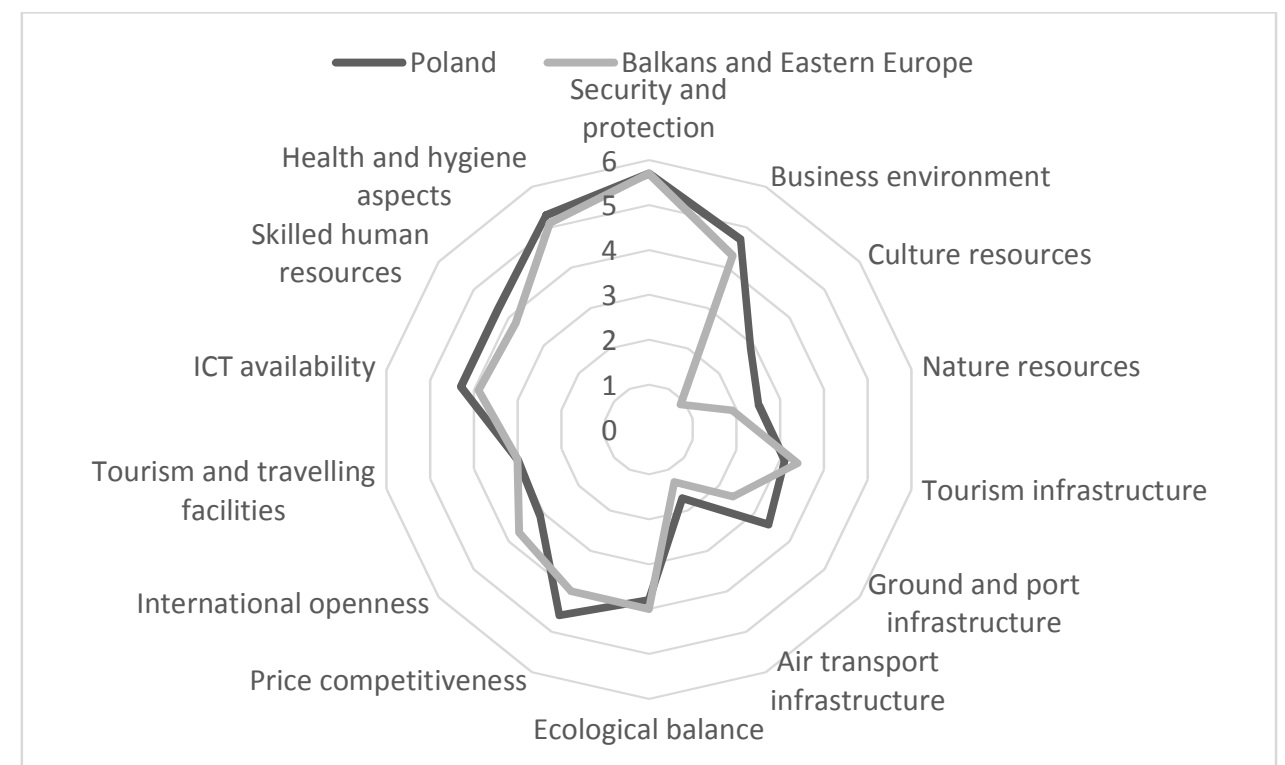

Source: Author's calculation based on the Travel and Tourism Competitiveness Index in 2017

Fig. 2. Tourist competitiveness of Poland, Balkans and Eastern Europe (scale 1-7)

The Figure 2 gives evidence that the nature and landscape values of agricultural land of Poland are very highly rated in Europe. Especially it relates to such indicators as Cultural resources, Nature resources, Ground infrastructure, Port infrastructure and Air infrastructure, Ecological balance, Price competitiveness, Availability of ICT and Appropriately specialized working staff. In fact, all the other indicators very insignificantly lag behind the Balkans and other East European countries as the sub-index values differ very slightly. The only one indicator which stands out from these indicators is International openness, which incorporates such sub-index components as Visa requirements, Openness of bilateral air service agreements and Number of regional trade agreements in force, which in reality is only indirectly linked with Poland's nature and landscape attractiveness as it mainly depends on the EU geopolitical aspects both in each of the analysed countries' regional and the overall global scale. Therefore, the authors' research findings give evidence that 13 years after Poland's accession to the European Union, growing number of consumers in European countries perceive Poland as an attractive region. This increases the importance of the tourism economy, which represents a very important source of income. Therefore, tourism policy makers of Poland have to consider the currents gaps in Poland's tourism international openness and to consider ways how to reduce them both at the local level and in discussions with other EU Member States.

\section{Conclusions, proposals, recommendations}

1) Contemporary surroundings enforce continuous changes of all market entities - institutions, enterprises and, above all, regions. Their flexible adaptation to the existing conditions of the competitiveness becomes a necessity and is determined by the possession and the skilful use of a variety of material resources and, in particular, the intangible resources. Towns and regions also compete with one another trying to attract tourists.

2) Poland's tourism competitiveness shows a positive trend as its position of the World Economic Forum Travel and Tourism Competitiveness Index is constantly improving (from the $27^{\text {th }}$ place in 2015 to the $25^{\text {th }}$ place in 2017).

3) In the analysed period, the Travel and Tourism Competitiveness Report shows that the most competitive countries were Spain, France, Germany and the United Kingdom, whereas the closest competitors of Poland were the Czech Republic, Hungary, Bulgaria, Slovakia and Latvia. 
4) The deeper insights in analysing the attractiveness of Poland compared with other East European and Balkan countries reveal that there are only few indicators Poland slightly lags behind the Balkans and other East European countries. The indicator which stands out from these indicators is International openness which incorporates such sub-index components as Visa requirements, Openness of bilateral air service agreements and Number of regional trade agreements in force.

5) The tourism policy makers of Poland have to conduct a deeper analysis of the currents gaps in Poland's tourism international openness and consider the possible ways how to reduce them by organizing discussions with local stake holders such as tourism operators and providers, NGOs, regional tourism authorities as well as by taking an active part in discussions with the EU Member States.

\section{Bibliography}

1. Chudy-Hyski, D. (2009). Uwarunkowania turystycznego kierunku rozwoju gorskich obszarow wiejskich polski, Krakow, s. 35.

2. Czudec, W. (2010), Konkurencyjnosc Regionow Polski Wschodniej. W: Zielinski Z. (red.), Rola informatyki w naukach ekonomicznych i spolecznych. Innowacje i implikacje interdyscyplinarne, z. 2/2010, Wyd. Wyzszej Szkoly Handlowej, Kielce.

3. Davidson, R. (1996). Turystyka. Wydawnictwo Polska Agencja Promocji Turystyki, Warszawa

4. Dabrowska, B.J. (2006). Rozwoj uslug turystycznych w warunkach globalizacji. Zarys problematyki, Wyzsza Szkola Turystyki i Hotelarstwa w Gdansku, Gdansk, s. 114.

5. Gaworecki, W. (2000). Turystyka. PWE, Warszawa.

6. Grabowski J. (2008). Uwarunkowania konkurencyjności turystycznej regionow, Ruch prawniczy, ekonomiczny i socjologiczny, Rok LXX, z. 3, ss. 149-164.

7. Grinberga-Zalite, G., Vitolina, Z., Rivza B. (2017). Knowledge and Skills Transfer for Sustainable Rural Tourism in the Baltic Sea countries. Turkish Online Journal of Educational Technology. - Special Issue for INTE 2017 (November 2017), pp. 350.-354.

8. Klamut, M. (2008). Konkurencyjnosc gospodarki regionalnej i lokalnej. W: Strzelecki Z. (red.), Gospodarka regionalna i lokalna, PWN, Warszawa.

9. Kraciuk, J. (2016). Konkurencyjnosc turystyczna Polski na tle krajow europejskich. W: Balinska A. (red.) Wyzwania rozwoju turystyki, SGGW Warszawa.

10. Krzyzanowska, K., Sikorska-Wolak I. (2010). Przedseębiorczosc w ujeciu teoretycznym i w praktyce. W: Krzyzanowska K. (red.) Przedsiebiorczosc na obszarach wiejskich - stan i perspektywy rozwoju, vol. 1, s. 39-41, Wydawnictwo SGGW, Warszawa.

11. Markowsk,i T. (1977). Konkurencyjnosc i wspolpraca wewnatrz regionalna podstawa nowoczesnej polityki rozwoju regionalnego. W: Mikolajewicz Z. (red.), Podstawowe problemy polityki rozwoju regionalnego $i$ lokalnego, Opole.

12. Markowski, T. (2005). Przedmiotowa i podmiotowa konkurencyjnosc regionow, KPZK PAN, Biuletyn, nr 219, Warszawa, ss. 24-37.

13. Ratajczak, W. (2008). Innowacyjnosc a konkurencyjnosc polskich regionow. W: Parysek J.J., Stryjakiewicz T., (red.) Region spoleczno-ekonomiczny i rozwoj regionalny, Poznan, Bogucki Wydawnictwo Naukowe.

14. Richter-Kazmierska, A. (2007). Partnerstwo na rzecz rozwoju regionalnego a konkurencyjnosc regionalna. W: Biernat T. (red.) Przedsiebiorstwo i panstwo - wybrane problemy konkurencyjności. Katedra Mikroekonomii Uniwersytetu Szczecinskiego, Szczecin.

15. Roszkowska-Madra, B. (2010). Obszary wiejskie o niekorzystnych warunkach gospodarowania w aspekcie ich zrownowazonego rozwoju, Uniwersytetu w Bialymstoku, 10.

16. Rosner, A. 2002. Wiejskie obszary kumulacji barier rowojowych. IRWiR, PAN Warszawa.

17. Rosner, A., Stanny M. 2007. Uwarunkowania, bariery, nowe rozwiazania instytucjonalne. "Nowe Zycie Gospodarcze" nr 21.

18. Sikora, J. (2014). Turystyka wiejska, w tym agroturystyka, w kontekscie perspektyw rozwoju wsi i rolnictwa w Polsce. Analiza wynikow badan empirycznych, Zesz. Nauk. Uniwersytetu Szczecinskiego, nr 807, Ekonomiczne Problemy Turystyki, nr 3(27), 113-126.

19. Stanny, M. (2013). Przestrzenne zroznicowanie rozwoju obszarow wiejskich w Polsce. Instytut Rozwoju Wsi i Rolnictwa Polskiej Akademii Nauk, Warszawa.

20.Szromek A.R. [bd]. Pomiar funkcji turystycznej obszarow za pomoca wskaznikow funkcji turystycznej na przykladzie obszarów państw europejskich https://www.ue.katowice.pl/fileadmin/_migrated/content_uploads/8_A.R.Szromek_Pomiar_Funkcji_Turystyc znej....pdf (data dostepu: 20.01.2018)

21. The Travel \& Tourism Competitiveness Report 2015. (2015). Growth through Shocks. World Economic Forum, Geneva. 
22. The Travel and Tourism Competitiveness Report 2017. (2017). Growth through Shocks. World Economic Forum, Geneva.

23. United Nations World Tourism Organization. Regional Department for Europe. Available: http://europe.unwto.org/. Retrieved: 20.03.2019

24. Warszynska, J., Jackowski, A. (1978). Podstawy geografii turyzmu, PWN, Warszawa.

25. Wielofunkcyjnosc rolnictwa. Kierunki badań, podstawy metodologiczne i implikacje praktyczne. (2010). Pod red. J. Wilkina. IRWiR PAN, Warszawa, 17.

26. Wilkin, J. (2007). Wielofunkcyjnosc rolnictwa i obszarow wiejskich. Wyzwania przed obszarami wiejskimi $i$ rolnictwem w perspektywie 2014-2020. „Nowe Zycie Gospodarcze” nr 21.

27. Winiarski, B. (1999). Konkurencyjnosc: kryterium wyboru czy kierunek strategii i cel pośredni polityki regionalnej? W: Klamut M. (red.) Konkurencyjnosc regionow, Wydawnictwo Akademii Ekonomicznej im. O. Langego we Wrocławiu, Wroclaw.

28. Wisniewska, A. (2008). Dochodowosc usług agroturystycznych w gospodarstwach kaszubskiej gminy Brusy, Slupskie Prace Geograficzne, nr 5, 221-225.

29.Zarebski, P. (2015). Wybrane elementy turystyki kulturowej jako czynnik rozwoju bazy noclegowej na obszarach wiejskich w Polsce http://turystykakulturowa.org/ojs/index.php/tk/article/viewFile/527/508

30. Zawadzki, P. (2014). Ekonomiczno-spoleczne uwarunkowania rozwoju agroturystyki w powiecie jeleniogorskim, Zesz. Nauk. Uniwersytetu Szczecinskiego, nr 806, Ekonomiczne Problemy Turystyki, nr 2(26), 315-329.

31.Zemla, M. (2010). Wartosc dla klienta w procesie ksztaltowania konkurencyjnosci obszarow recepcji turystycznej. Wydaw. GWSSH w Katowicach, Katowice.

32.Zvirbule A., Dobele A. (2018). Gastronomic Tourism in Latvia: Features and Opportunities for Development. IX International Scientific Agriculture Symposium „AgroSym 2018”: Book of proceedings, Jahorina, Bosnia and Herzegovina, 4-7 October 2018 / University of East Sarajevo, Faculty of Agriculture. - Jahorina, 2018. pp. 1911-1916. 